\title{
Japan's Influence on the International Investment Pattern of "The Belt and Road"
}

\author{
Ping Lv \\ School of Economics \& Management \\ Nanjing University of Science and Technology \\ Nanjing, China
}

\begin{abstract}
The Belt and Road" initiative is an important supporting point for China's future economic growth, but this initiative will undoubtedly be affected by Japan. Japan's perception and response to the initiative of "The Belt and Road" are gradually changing and have a positive trend. This paper analyzes the development status of the countries along the Belt and Road and uses decades of data to depict the trade pattern of the areas along the Belt and Road. At the same time, it reviews Japan's investment in countries along "The Belt and Road" and finds it shows the characteristics that "Asia hot but Europe cold", and then analyzes its future investment trends in Southeast Asia and South Asia. As to Japan's influence on the international investment pattern of "The Belt and Road", Japan's investment in China is declining. Japan's investment in Southeast Asia and India will pose challenges to "The Belt and Road" initiative. China and Japan have common interests in "The Belt and Road" and they can actively seek cooperation and gain win-win results.
\end{abstract}

Keywords-China; Japan; The Belt and Road; international investment

\section{INTRODUCTION}

Since the introduction of Chairman Xi Jinping in 2013, "The Belt and Road" has rapidly upgraded to the national initiative. The proposal of "The Belt and Road" has aroused strong reaction from neighboring countries and regions and even the whole world. The emphasis that taking development as a priority in the construction of the "The Belt and Road" not only reflects the consistency of China's domestic and international goals, but also provides insights for the countries along the route to understand the commonality of the "The Belt and Road." Only with this common goal and common interests, "The Belt and Road" can be better and exert its overall effect.

The initiative direction of "The Belt and Road" mainly involves five links. China, as a world power, actively proposes building a cooperation framework through "The Belt and Road" initiative and hopes that countries along the route can participate together. However, whether the countries along "The Belt and Road" initiative can actively respond to China can't be sure, and it depends on China's relative importance in the economic development of these countries.

\section{JAPAN'S COGNITION AND RESPONSE TO THE CONCEPT OF "THE BELT AND ROAD"}

Japan's reaction to "The Belt and Road" initiative is a changing process. At the beginning, Japanese companies and governments mostly opposed the initiative, and considered it is not positive to Japan's economic development and would break its economic dominance in Asia. However, with the advancement of the initiative, Japan has also benefited a lot, and the public opinion of the Japanese people and government officials has begun to divide.

At the same time, the staged achievements of "The Belt and Road" have brought Japan a certain sense of crisis. The Japanese government has accelerated its visits and cooperation with the countries along "The Belt and Road" and strengthened competition with China in many aspects, especially in the AIIB.

The attitude of the Japanese government and a considerable part of the companies has changed with the delightful development of "The Belt and Road" and the AIIB. They hope that the government can consider joining "The Belt and Road" and AIIB. Moreover, with the increasing of the economic benefits from "The Belt and Road" and the Asian Investment Bank to the participating countries, the academic community believes that the Japanese government may participate to "The Belt and Road" initiative as well as join the AIIB in the future.

\section{The DeVelopment Status of COUnTRIES AlONG "THE BELT AND ROAD" INITIATIVE}

The author divided the countries into five stages according to the GNI, as shown in "Table I". In 2015, the population of the countries along "The Belt and Road" and the level of economic growth at the four income levels have the following characteristics: 
TABLE I.

The Development Stage of Countries Along "The Belt And RoAD" (2010-2015)

\begin{tabular}{|c|c|c|c|c|c|}
\hline No. & Groups & $\begin{array}{l}\text { Per Capital } \\
\text { (GNI) }\end{array}$ & $\begin{array}{l}\text { Population } \\
\text { (million) }\end{array}$ & \begin{tabular}{|c|} 
Manufacturing \\
value added as \\
a share of GDP \\
$(\%)$ \\
\end{tabular} & $\begin{array}{c}\text { 2010-2015 GDP } \\
\text { growth rate } \\
(\%)\end{array}$ \\
\hline 1 & United States & 55980 & 321 & \begin{tabular}{|c|}
12.3 \\
\end{tabular} & 2.2 \\
\hline 2 & High-income countries & 41925 & 1187 & 14.8 & 1.9 \\
\hline 3 & $\begin{array}{c}\text { B\&R High-income } \\
\text { countries }\end{array}$ & 27702 & 195 & 16.8 & 3 \\
\hline 4 & $\begin{array}{c}\text { Upper middle-income } \\
\text { countries }\end{array}$ & 8255 & 2593 & 21 & 5.1 \\
\hline 5 & China & 7930 & 1371 & 29.7 & 8.3 \\
\hline 6 & $\begin{array}{l}\text { B\&R upper middle- } \\
\text { income countries }\end{array}$ & 7123 & 529 & 14.7 & 3.5 \\
\hline 7 & $\begin{array}{c}\text { Lower middle-income } \\
\text { countries }\end{array}$ & 4508 & 2927 & 16.4 & 5.7 \\
\hline 8 & $\begin{array}{l}\text { B\&R Lower middle- } \\
\text { income countries }\end{array}$ & 2309 & 2399 & 14.8 & 5.9 \\
\hline 9 & Low income countries & 2032 & 638 & 8.2 & 5.4 \\
\hline 10 & $\begin{array}{l}\text { B\&R Low income } \\
\text { countries }\end{array}$ & 670 & 61 & 9.2 & 4.9 \\
\hline 11 & World & 10548 & 7346 & 15 & 3 \\
\hline
\end{tabular}

There are 20 countries with high income levels along "The Belt and Road", accounting for $16.4 \%$ of the global population with this level of development. The added value of manufacturing in GDP accounted for $16.8 \%$, which is slightly higher than that of countries with the same income level in the world. The growth rate of the economy between 2010 and 2015 reached 3\%, which is significantly higher than that of countries at the same level in the world.

There are 21 countries in the upper middle-income levels along "The Belt and Road", accounting for $20.4 \%$ of the global population with this level of development. The added value of their manufacturing industries accounted for an average of $14.7 \%$ of GDP, which is significt that of countries with the same level of global income.

\section{AREAS Along "The Belt AND RoAD" AND THE TRADE PATTERN BETWEEN CHINA AND JAPAN}

Since 2000, the areas along "The Belt and Road" have experienced significant growth in the total volume of trade between China and Japan. The total trade volume and growth rate of China along the "The Belt and Road" regions during the observation period are significantly higher than those of Japan, which means that the trade dependency between China and the region along the route significantly exceeds that of Japan. (See "Table II")

TABLE II. The Proportion of "The Belt AND RoAD" Countries Trade With China AND JAPAN IN THE Region (2014)

\begin{tabular}{|c|c|c|c|c|c|c|}
\hline \multirow{2}{*}{ Target Country } & \multicolumn{3}{|c|}{ China (\%) } & \multicolumn{3}{c|}{ Japan (\%) } \\
\cline { 2 - 7 } Reporting Country & $I M P$ & $E X P$ & $\begin{array}{c}\text { Total } \\
\text { Amount }\end{array}$ & $I M P$ & EXP & $\begin{array}{c}\text { Total } \\
\text { Amount }\end{array}$ \\
\hline North-east Asia & 49.45 & 38.13 & 43.80 & 46.36 & 53.19 & 49.10 \\
\hline Southeast Asia & 23.14 & 25.7 & 24.42 & 20.65 & 32.51 & 25.39 \\
\hline South Asia & 2.48 & 10.54 & 6.50 & 1.73 & 3.39 & 2.40 \\
\hline West Asia & 20.33 & 17.23 & 18.78 & 30.28 & 9.12 & 21.81 \\
\hline $\begin{array}{c}\text { Central and Eastern } \\
\text { Europe }\end{array}$ & 2.02 & 5.39 & 3.70 & 0.82 & 1.48 & 1.09 \\
\hline Central Asia & 2.58 & 3.02 & 2.80 & 0.15 & 0.30 & 0.21 \\
\hline
\end{tabular}

To examine the importance of the trade between China and Japan in all regions along the route, we should observe the increase in the proportion of trade as well as the absolute size of trade. Firstly, the proportion of total trade volume and import and export trade between China and the region along the route has generally increased during the observation period. Central Asia, West Asia, and Southeast Asia have the largest increase in the proportion of China's trade. At the same time, except for West Asia, the proportion of total trade volume and import/export trade between Japan and the region along the route showed a downward trend during the observation period. The largest decline was in South Asia, 
where the proportion of total trade volume and import/export trade decreased by $2.81 \%, 2.38 \%$ and $3.20 \%$. Obviously, the increase in the proportion of trade to China across all regions is significantly higher than that of Japan. Second, in 2014, the proportion of China's total trade, import and export trade in all regions along the route was higher than that of Japan.

In addition, in "Table II", the ratio of total trade and import/export trade between China and Japan in the total volume of Sino-Japanese trade in the region along "The Belt and Road" area was calculated. If China further deepens its development of trade with Northeast Asia, Southeast Asia, and West Asia, the trade balance between Northeast Asia, Southeast Asia, and West China is likely to decrease, as for China, in order to protect the development of its international trade and ensure its position in the international trade in the process of promoting "The Belt and Road", Japan is likely to expand its core position in Asia's industrial division of labor. The reduction of direct investment in China by foreign direct investment in these regions, while on Japan's trade, is also weakening the proportion of China's trade in Northeast Asia, Southeast Asia, and West Asia, so as to achieve the purpose of counterbalance China's influence in the above areas.

\section{JAPAN'S INVESTMENT OVERVIEW AND TRENDS IN COUnTRIES AlONG "The Belt AND RoAD"}

Japan's pattern of foreign investment along "The Belt and Road" region shows the Asia hot and Europe cold. The Japanese government has guided multinational corporations using their geopolitical advantages in Asia. As shown in "Table III", Japan's investment in Asia along "The Belt and Road" is mainly concentrated in Pakistan and India in South Asia, Singapore, Thailand, Philippines, Malaysia and Indonesia in Southeast Asia. In particular, the traditional five ASEAN countries are all on the scale of 100 billion yen or more. At the same time, Japan's overseas investment in Southeast Asia and South Asian countries not only showed a rapid growth but also showed strong growth momentum.

TABLE III. JAPAN'S INVESTMENT IN "The BeLt AND RoAD" InITIATIVE BetweEn 2014 AND 2016 (Unit: 100 MiLLION YeN)

\begin{tabular}{|c|c|c|c|c|c|c|c|}
\hline Countries & $\mathbf{2 0 1 4}$ & $\mathbf{2 0 1 5}$ & $\mathbf{2 0 1 6}$ & Countries & $\mathbf{2 0 1 4}$ & $\mathbf{2 0 1 5}$ & $\mathbf{2 0 1 6}$ \\
\hline Malaysia & 1299 & 3565 & 1599 & Kazakhstan & 27 & 1 & 146 \\
\hline Philippines & 986 & 1836 & 2483 & Slovakia & -14 & -4 & 465 \\
\hline India & 2556 & -1441 & 4018 & Saudi Arabia & 924 & 785 & 132 \\
\hline Singapore & 8657 & 8197 & -20360 & Poland & 20 & 8 & 117 \\
\hline Thailand & 5764 & 4391 & 3830 & Bulgaria & 0 & -14 & 1 \\
\hline Indonesia & 5127 & 3926 & 3220 & Latvia & 1 & 27 & 57 \\
\hline Mongolia & 6 & 32 & 21 & Hungary & 27 & 3 & 32 \\
\hline Vietnam & 1734 & 1740 & 2003 & Romania & 29 & -94 & -69 \\
\hline Brunei & 17 & 15 & 29 & Ukraine & 54 & 50 & 175 \\
\hline Cambodia & 311 & 273 & 127 & $\begin{array}{c}\text { Czech } \\
\text { Republic }\end{array}$ & 145 & 422 & 52 \\
\hline Myanmar & 115 & 625 & 152 & $\begin{array}{c}\text { United Arab } \\
\text { Emirates }\end{array}$ & -239 & -210 & 3 \\
\hline Russia & 401 & 639 & -96 & Iraq & 0 & 2 & 18 \\
\hline Montenegro & 1 & 0 & 14 & Bahrain & 7 & 0 & 79 \\
\hline Turkey & 335 & 538 & 0 & Israel & 29 & 9 & 222 \\
\hline Pakistan & 97 & 117 & 100 & Jordan & 1 & 47 & 2 \\
\hline Sri Lanka & 5 & 29 & 22 & Egypt & 61 & -0 & 1155 \\
\hline Maldives & 2 & 5 & 16 & Kuwait & 20 & 34 & 1 \\
\hline Croatia & 1 & 1 & -1 & Qatar & -51 & 12 & 35 \\
\hline Slovenia & 5 & 32 & 2 & Oman & 2 & 194 & 9 \\
\hline
\end{tabular}

Data Sources: According to the Bank of Japan(http://www.boj.Or.jp/statistics).

Japan's investments in the Middle East region and European countries along "the Belt and Road Initiative" are much smaller than in Asian neighboring countries. However, the five countries of the Czech Republic, Israel, Slovakia, Kazakhstan, and Russia have a large amount of investment, which is basically around 10 billion yen, and the high year amounts to 50 billion yen. In recent years, the demand for energy and transportation infrastructure has increased. The Japanese government seized the opportunity to actively strive for the infrastructure market in these two regions and guide related companies to invest. (See "Table IV")

TABLE IV. JAPAN's MANUFACTURING INVESTMENT IN SOUTHEAST ASIA AND SOUTH ASIA (UNIT:100 MiLLION YEN)

\begin{tabular}{|c|c|c|c|c|c|c|c|c|c|c|c|c|c|c|}
\hline Countries & 2005 & 2006 & 2007 & 2008 & 2009 & 2010 & 2011 & 2012 & 2013 & 2014 & 2015 & 2016 & 2017 & 2018 \\
\hline India & 290 & 474 & 407 & 5115 & 729 & 1579 & 924 & 1473 & 1886 & 1291 & 1306 & 1498 & 1953 & 2204 \\
\hline Indonesia & 1115 & 662 & 637 & 195 & 519 & 315 & 1487 & 2241 & 1596 & 1842 & 1642 & 1695 & 2300 & 2371 \\
\hline Philippines & 613 & 289 & 265 & 473 & 647 & 301 & 431 & 453 & 625 & 974 & 1143 & 1091 & 1141 & 1192 \\
\hline Vietnam & 202 & 437 & 478 & 745 & 452 & 345 & 854 & 1211 & 1818 & 898 & 1300 & 1499 & 1655 & 1764 \\
\hline Malaysia & 350 & 3321 & 149 & 296 & 424 & 548 & 706 & 466 & 772 & 1073 & 1192 & 1362 & 1252 & 1206 \\
\hline Singapore & 692 & 642 & 1020 & 300 & 567 & 2225 & 1400 & 1195 & 561 & 2089 & 2396 & 2728 & 2596 & 2453 \\
\hline Thailand & 1328 & 2152 & 3001 & 1933 & 1235 & 1599 & 2211 & 2988 & 3469 & 5592 & 5584 & 6129 & 7814 & 7713 \\
\hline Total Southeast Asia & 4590 & 7977 & 6957 & 3995 & 3852 & 5336 & 7132 & 10027 & 8939 & 13759 & 14563 & 16002 & 18711 & 18903 \\
\hline
\end{tabular}


"Table IV" shows the scale of Japan's manufacturing investment in Southeast Asia and South Asia (India) from 2005 to 2018. Japan's manufacturing investment in Southeast Asia grew steadily from 459 billion yen in 2005 to $1,890.3$ billion yen in 2018, and especially accelerated the pace of manufacturing in Singapore and Thailand. Survey Report on Overseas Business Operations by Japanese Manufacturing Companies-Results of the JBICFY2018 Survey released by the Japan Bank for International Cooperation (JBIC) shows the five promising countries and regions for Japanese manufacturing overseas business over the next three years. China maintained the top position, India fell to the second since FY2017, Thailand rose to the third place, Vietnam and Myanmar came to the fourth and fifth respectively. Moreover, Singapore has become the preferred location for Asia-Pacific headquarters of Japanese multinationals in recent years. Asian countries have become the core area for the "The Belt and Road" between Japan and China.

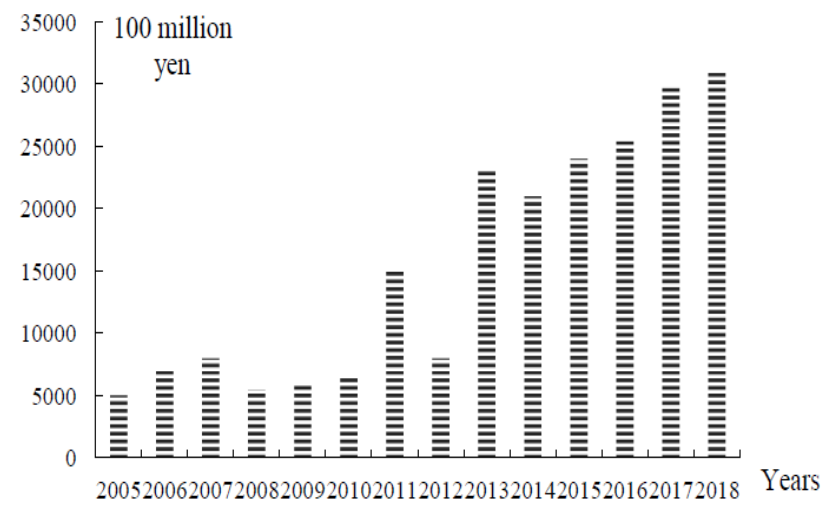

Fig. 1. Japan's investment in Southeast Asia, 2005-2018.

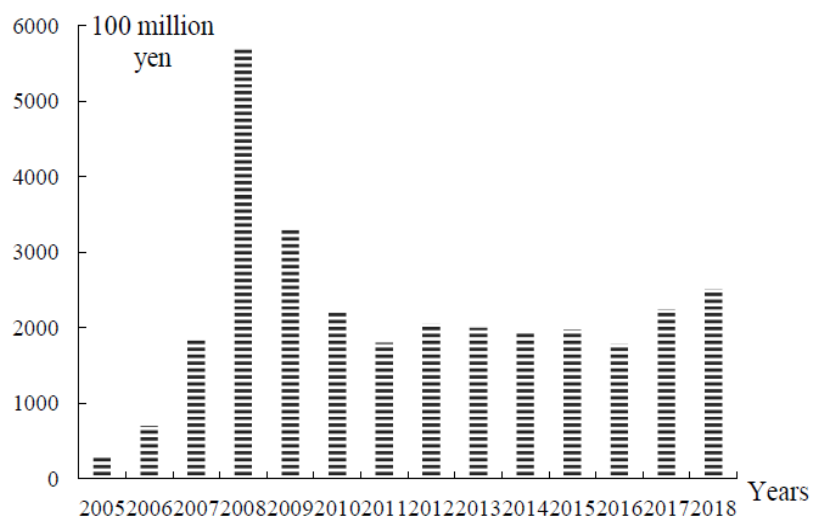

Fig. 2. Japan's investment in South Asia, 2005-2018.

"Fig. 1" and "Fig. 2" list the OFDI investment trends in Southeast Asia and South Asia from 2005 to 2018. In 2005, Japan invested 555.7 billion yen in Southeast Asia, and then grew rapidly. Because of the financial crisis in 2008, the pace of foreign investment slowed down. Two years later, it returned to the growth track and broke the trillion yen mark in 2011, and then exceeded 2 trillion yen in 2013. Between 2013 and 2018, it has been maintaining solid growth. Japan's foreign investment in Southeast Asia showed strong growth momentum in the past two years, and the overall size of investment has stabilized at more than 3 trillion yen each year, showing Japan's strong political and economic influence in this region. In contrast, Japan's foreign investment in South Asia has exceeded 200 billion yen in all other years, except for the breakthrough of 500 billion yen in 2008. Japan's investment in South Asia is mainly in India, and its influence in Pakistan and other South Asian countries is still limited.

Unlike Japan's investment in Europe and the United States, Japan's foreign investment in Asian countries is mainly about manufacturing. In Asia, Japan is mainly based on a gradient of industrial transfer, shifting its comparative advantage to a relatively surplus domestic industry to Asian neighbors, providing space for domestic industrial transformation and upgrading.

\section{JAPAN'S INFLUENCE ON "THE BELT AND ROAD" INTERNATIONAL INVESTMENT PATTERN}

\section{A. Impact on Japanese Foreign Investment in China}

Japan's foreign investment along "The Belt and Road" Asian countries, especially Southeast Asian countries, has a large impact on Japan's investment in China in both scale and structure. As shown in "Fig. 3", the scale of Japan's investment in China has been stagnating for about US\$3.5 billion from 2007 to 2010. After showing a rebound in 2012, it has begun to decline again in 2014. Second, in terms of investment structure, Japan's expansion of manufacturing investment in Southeast Asia and India will directly affect Japan's manufacturing investment in China. In recent years, the rising costs of workers' lives and enterprises' production driven by rising house prices in China have finally led to transnational corporations, causing some labor-intensive enterprises to move out of China and choosing to produce in countries with lower production costs in Southeast Asia. Japan's many transnational manufacturing investments in Southeast Asia fall into this category. This part will replace the Japanese capital that would have flowed to China. It may also lead to the relocation of Japan's former manufacturing industries to Southeast Asia, and eventually show Japan as shown in "Fig. 3". The scale of investment in China showed a downward trend.

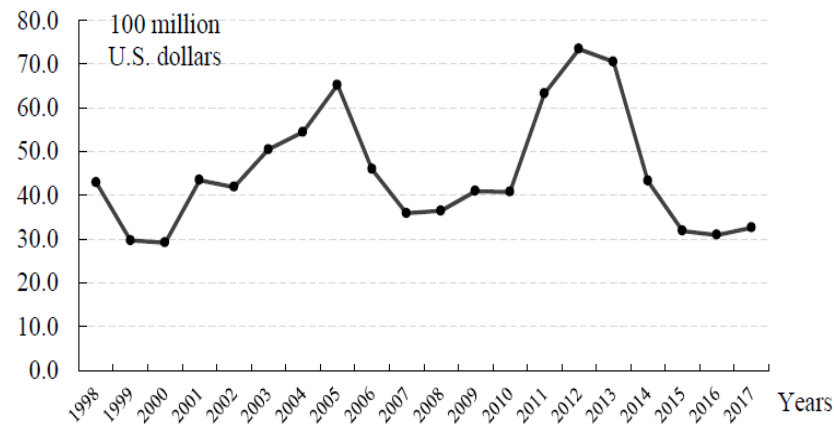

Fig. 3. Trend of Japanese investment in China.

Data sources: The Bank of Japan (http://www.boj.Or.jp/statistics) 


\section{B. The Challenge for China's "The Belt and Road" Initiative}

For a long period of time, Japan's foreign investment in Southeast Asia and India has gradually built up Japan's political and economic influence in this region. Meanwhile, Japan has started a series of investments and strategic actions in Asia countries, and posed a serious challenge to China's implementation of "The Belt and Road". Japan's investment in this region will directly squeeze China's outbound investment in Southeast Asia.

\section{CONCLUSION}

China and Japan should actively seek cooperation and gain win-win results. In recent years, Japan has continuously increased its strategic investment in countries in Southeast Asia and South Asia and actively developed its political and economic relations with Japan. At the same time, Japan is also seeking to increase its influence in Central Asia. Japan's accelerated direct investment in Southeast Asia and South Asia has had a certain impact on Sino-Japanese economic relations and has also led to increased competition between China and Japan at the regional and multilateral levels. At the same time, however, China and Japan are also facing major opportunities to cooperate and promote mutual trust based on "The Belt and Road" multilateral framework.

Above all, China and Japan can join forces to accelerate the process of regional economic integration. accelerate the process of cooperation between RCEP, China, Japan and South Korea FTA and other integrated organizations, it will not only contribute to the stability and prosperity of the region, but also conducive to creating a more convenient and competitive investment environment.

Second, China and Japan must work together to promote the infrastructure development in the Asia Pacific region. If China and Japan can realize healthy competition and mutually beneficial cooperation in the field of improving infrastructure, it is possible to obtain multiple benefits, such as jointly increasing bargaining power, promoting exports of infrastructure products, improving logistics efficiency and reducing logistics costs.

Finally, China and Japan can open financing channels through cooperative financing. In the financial sector, the Silk Road Fund, the Asian Investment Bank and the BRICS Development Bank, which China has actively established, have all been officially launched. Japan, on the other hand, has repeatedly offered to promote cooperation financing between the Asian Investment Bank and Asian Development Bank, the prospects for cooperation between China and Japan are promising in terms of smooth financing channels and cooperation in finance.

\section{REFERENCES}

[1] Nie Aiyun, Zeng Jianfeng. The Inspiration of American and Japanese Investment Experience on China's "One Belt and One Road" Investment [J]. Research of Finance and Education, 2018,31(01):4551.
[2] Wang Congyang. China's Investment and Trade in Countries along "The Belt and Road" [J]. Chinese Collective Economy, 2018(01):2829.

[3] He Xiaogang. Enlightenment of Japan's Experiences and Lessons from Countries along "The Belt and Road" to China [J]. Intertrade, 2017(11):52-56.

[4] Zhao Yuming. "The Belt and Road" under the Vision of the Japanese Academic Community [J]. Eurasian Economy, 2017(04):56$66+126+128$

[5] Wang Dan. Research on the External Investment Risk Managemen of Chinese Enterprises in the Background of "The Belt and Road" [J]. Modern Marketing (Last Edition), 2017(06):30

[6] Wang Guangtao. B When TPP suffers "The Belt and Road": Japan's Strategic Predicament and Policy Options [J]. Research on International Relations, 2017(03):129-145+157-158

[7] Zhong Feiteng. The Relationship Between "The Belt and Road" and the New Type of Globalization and Great Powers [J]. Journal of Foreign Affairs Review, 2013,34(03):1-26.

[8] Song Jinxin. Summary of Researches on Related Issues of "The Belt and Road" and Japan [J]. Journal of Fujian Institute of Socialism 2017(01):82-88.

[9] Meng Huaqiang. The Enlightenment to "The Belt and Road" initiative from the Financial Support System of Japanese Enterprises on Foreign Investment [J]. Review of Economic Research, 2016(67):10 12.

[10] Pang Deliang,Liu. Shengjun. Evolution of the China-Japan Trade Patterns Along the Belt and Road Initiative [J]. Northeast Asia Forum, 2016, 25(06):36-45+125

[11] Ding Man. Cooperation between China and Japan on "The Belt and Road" or a Confrontation [J]. Russia, Eastern Europe, Central Asia, 2016(05): 119-131+158.

[12] Du Ying. The Suggestions on Promoting Japan's Participation in the "Belt and Road" [J]. Journal of Mudanjiang Teachers College (Philosophy and Social Science), 2016(03):19-24.

[13] Chang Sichun. Japan's Investment Pattern along "The Belt and Road" and its Impact on China [J]. Northeast Asia Journal, 2016(03):39-45

[14] Xu Yuanrong. How does Japan Regard "The Belt and Road" [N] First Financial Daily, 2015-08-11(013)

[15] Li Suhua. Japan's Cognition and Response to the Concept of "The Belt and Road" [J]. Northeast Asia Journal, 2015(03):15-19.

[16] Ding Hongwei. The Transformation and Upgrading of China-Japan Economic and Trade Cooperation - Manufacturing Competitiveness and Its Influencing Factors [C]. Proceedings of the National Japan Economic Association, 2015: 165

[17] Meltem engün Ucal. Panel Data Analysis of Foreign Direct Investment and Poverty from the Perspective of Developing Countries [J]. Procedia Social and Behavioral Sciences, 2014(109).

[18] Mingxing Chen,Zhipeng Tang,Yongping Bai,Xiaoping Zhang. Relational Pattern of Urbanization and Economic Development: Parameter Re-evaluation of the Chenery Model [J]. Journal of Geographical Sciences, 2015, 25(8). 